\title{
МОЖЛИВОСТІ ЗБЕРЕЖЕННЯ ПСИХОЛОГІЧНОГО БЛАГОПОЛУЧЧЯ В СИТУАЦІї ПАНДЕМІЇ
}

\author{
Наукова доповідь на методологічному семінарі НАПН України \\ «Актуальні проблеми психологічної протидії негативним інформаційним \\ впливам на особистість в умовах сучасних викликів» 8 квітня 2021 р.
}

https://doi.org/10.37472/2707-305X-2021-3-1-13-6

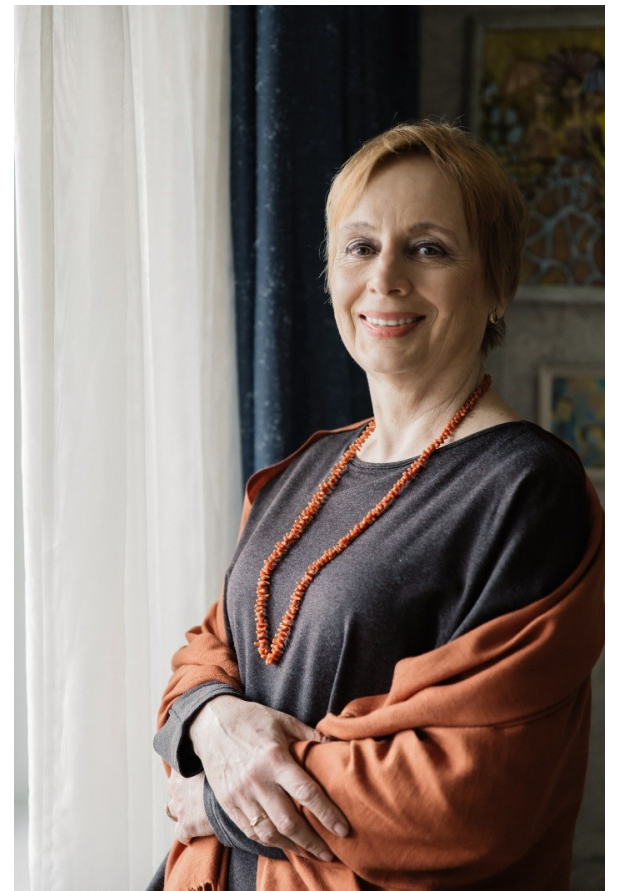

TИТАРЕНКО

Тетяна Михайлівна

доктор психологічних наук,

профресор, дійсний член

(академік) НАПН України,

головний науковий співробітник

лабораторії соціальної психології

особистості lнсmumymy

сочіальної та політичної

психології Національної академії

педагогічних наук України,

м. Київ, Україна

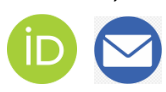

Анотація. Визначено, що можливості збереження психологічного благополуччя в ситуації пандемії пов'язані (1) з життєвою ситуачією, яку людина певним чином сприймає, оцінює, переживає; (2) зі змінами у житті, які проявляються в особливостях зв'язку переосмисленого минулого, оновленого теперішнього і більш-менш прогнозованого майбутнього; (3) із иіннісно-смисловими характеристиками, що проявляються у відповідних ландшафтах життетворення. 3'ясовано, що найбільш позитивно впливає на актуальний стан психологічного благополуччя ландшафт саморозвитку. Мають свою специфіку і способи збереження психологічного благополуччя, які використовують представники прагматичного, комунікативного, соиієтального, волонтерського ландшафтів. У більш віддаленій часовій перспективі психологічне благополуччя може залежати і від якості переосмислення травматичного досвіду, що забезпечує екзистенційний ландшафт життєтворення.

Сочіальна і психологічна підтримка за участі психологів, психотерапевтів, соціальних працівників, представників громад надається тим людям, яким не вистачає внутрішніх ресурсів для підтримки психологічного благополуччя. Ефективною формою підтримки стає соиіально-психологічний супровід як медіатор особистісного життєтворення, що передбачає відновлення психологічного здоров'я, життєстійкості, покращення стосунків з оточенням, повнішу професійну самореалізацію.

Ключові слова: психологічне благополуччя; оцінка карантинної ситуації; зміни в минулому-теперішньому-майбутньому; ціннісносмислові характеристики життя; ландшафт життєтворення; пандемія COVID-19.

Вже більше року людство живе в жорстких умовах численних загроз і обмежень, які несе пандемія COVID-19. Відчутних змін зазнала наша повсякденність, яка завжди сприймалася як джерело спокою, стабільності, передбачуваності, інколи монотонності і нудьги. Тепер, коли повсякденні практики вимушено стали нетиповими, неповторюваними, змінними, людина опинилася без звичних точок опори і частково втратила психологічне благополуччя (Титаренко, 2020а).

Говорячи про психологічне (суб'єктивне, внутрішнє) благополуччя в умовах пандемії, ми, безумовно, спираємось на такі популярні концепти як щастя, задоволеність життям, добробут (Гаврищак \& Борисенко, 2019; Гілберт, 2019; Максименко \& ЛущПурій, 2020; Brooks et al., 2017). Але розглядатимемо психологічне благополуччя насамперед у контексті особистісного життєтворення (Слюсаревський, 2020; Титаренко, 2020b). 
Достатній рівень благополуччя передбачає не лише повсякденну задоволеність особистості власним життям, а й готовність щось у цьому житті оперативно змінювати відповідно до обставин. Шлях до підвищення благополуччя це шлях все більш невимушених імпровізацій на тему, яку задає значуща подія з усією її раптовістю. Пандемія вимагає від нас готовності змінюватися, імпровізувати з онлайн і офлайн зайнятістю, 3 інакшими способами заробляння грошей, 3 власними планами на майбутнє, способами спілкування та відпочинку. І всі ці імпровізації мають бути не надто ризикованими, щоб не призвести до деструктивних наслідків.

Пандемічні життєві обставини у багатьох людей підвищують готовність покидати звичну зону комфорту і виходити у сферу непередбачуваного, неочікуваного, непрогнозованого. Для цього потрібна неабияка особистісна гнучкість, що передбачає здатність модифікувати короткострокові і довготривалі життєві проєкти відповідно до щоденних викликів соціуму. Отже, психологічне благополуччя забезпечується здатністю відповідально творити власне життя в умовах, що склалися, щоденно його змінювати, коригувати, враховуючи внутрішні ресурси і зовнішні виклики (Титаренко, 2020b).

Щоб конкретизувати чинники, які впливають на психологічне благополуччя у пандемічних умовах, розглянемо, з чого складається структура пандемічної повсякденності.

По-перше, це нав'язана коронавірусом життєва ситуація, яку людина певним чином сприймає, переживає, усвідомлює, тлумачить.

Кожну життєву ситуацію можна оцінювати порізному, і від ставлення до неї залежить, чи збереже людина власне психологічне благополуччя, чи втратить його.

Новий життєвий досвід, який людина отримує під час пандемії, сприймається більшістю як екстраординарний, несхожий на будь-який попередній. Така індивідуальна унікальність переживань супроводжується не менш унікальним почуттям спорідненості, спільності з усіма мешканцями планети Земля, що опинилися у схожих загрозливих обставинах.

Емпіричне дослідження проводилося з використанням засобів хмарного сервісу «Google форми» навесні 2020 р., на вибірці з 326 учасників (168 жінок і 158 чоловіків).

За нашими даними, ставлення людини до пандемічної життєвої ситуації, що включає

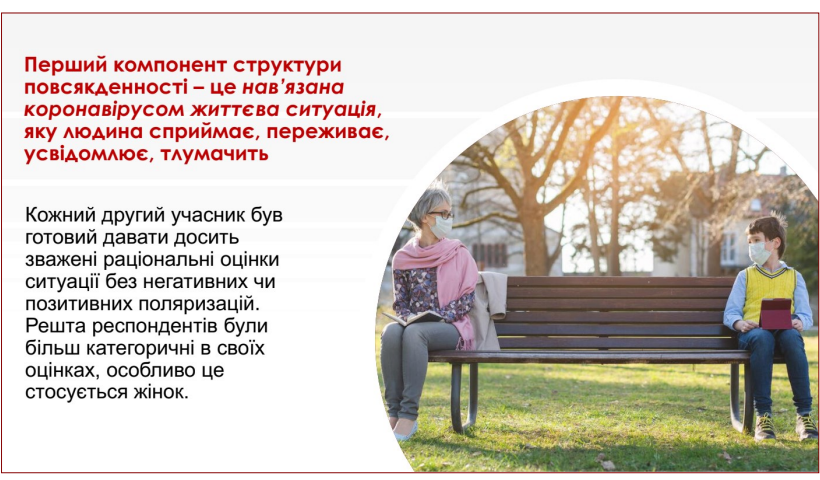

сприймання, оцінку, переживання нових загрозливих обставин, безпосередньо впливає на можливості збереження психологічного благополуччя. Переважна більшість людей усвідомлює вплив непростих життєвих обставин, в яких вони опинилися і не можуть змінити, на процес життєтворення. Вони аналізують ці обставини окремо від змін у власному житті, на які мають вплив. Практично кожний другий учасник був готовий давати досить зважені раціональні оцінки ситуації без негативних чи позитивних поляризацій. Решта респондентів були більш категоричні в своїх оцінках, особливо це стосується жінок. У всіх вікових групах, крім юнацької, частіше зустрічалися негативні описи ситуації, і ця негативність росла разом із зростанням віку респондентів (Титаренко, 2020b).

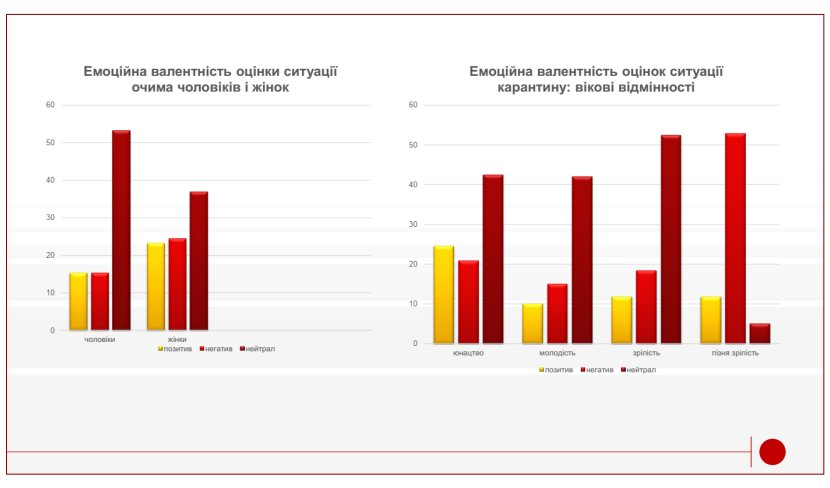

По-друге, до структури пандемічної повсякденності входять реальні зміни, які особистість вносить у власне життя.

Ці зміни проявляються в трьох часових діапазонах, в яких розгортається життя кожної людини: минулому, теперішньому і майбутньому. У часи пандемії теперішнє видозмінюється, оновлюється, хоча, можливо, частина людей це й заперечує. Минуле переосмислюється, переструктуровується, інакшим чином згадується і оцінюється. Відчутних змін набуває і майбутнє, яке базується на трансформаціях минулого і теперішнього. Очікування віднині базуються на певному спектрі емоційних станів: тривожних, пригніче- 


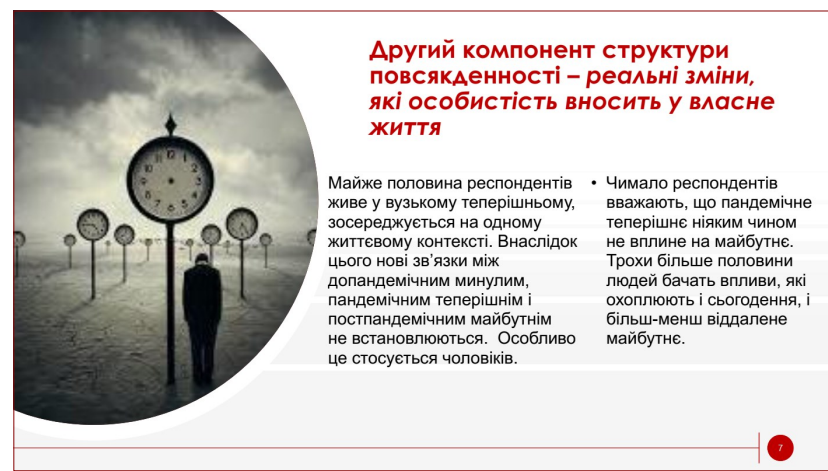

них, напружених, інколи ейфорійних, завдяки чому втрачають чіткість і змістову конкретність. Горизонти майбутнього звужуються, прогнозованість падає. Далекі масштабні цілі відсуваються на невизначений термін або скасовуються, заміняючись на більш прості і короткострокові.

Психологічне благополуччя, що передбачає здатність приймати власне минуле, насолоджуватися сьогоденням і вірити у краще майбутнє, в часи пандемії починає видозмінюватися в кожному з часових діапазонів. Теперішнє не дає підстав для насолоди буттям, вимагаючи від людини переструктурування власної повсякденності. Незрозумілою залишається тривалість нової життєвої реальності, що теж знижує рівень суб'єктивного благополуччя. Якщо людина сприймає зміни у житті як вимушені, примусові, її ставлення до теперішнього іррадіює на минуле. У такому випадку вже пережите починає все негативніше емоційно забарвлюватися, і ступінь прийняття власного минулого падає. Повна невизначеність майбутнього і переживання браку суб'єктності, неможливості у звичному режимі керувати власним життя доповнює картину крихкості щоденного існування.

За нашими даними майже половина респондентів живе у вузькому теперішньому, зосереджується на одному життєвому контексті. Внаслідок цього нові зв'язки між допандемічним минулим, пандемічним теперішнім і постпандемічним майбутнім не встановлено. Особливо це стосується чоловіків. Найбільш спрощеною виглядає

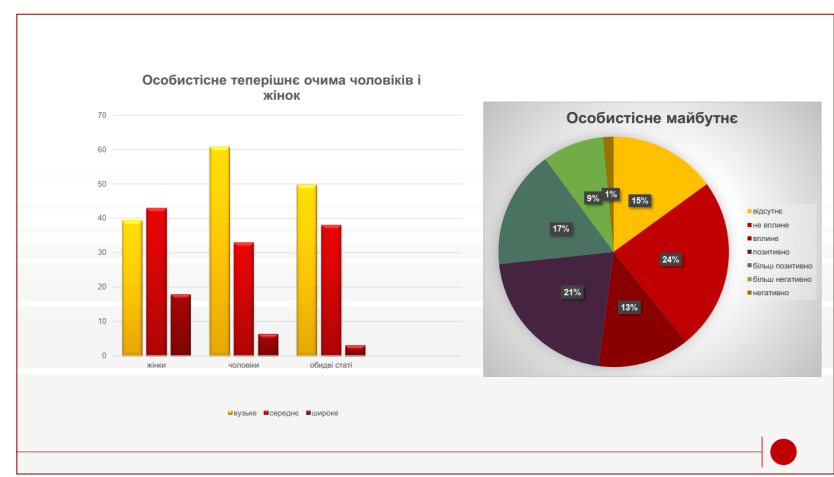

текстура повсякденності у юнацькій групі. 3 роками ця текстура стає все більш складною, щільною, а теперішнє включає все більше життєвих контекстів, набуває ширшого масштабу.

Чимало респондентів вважають, що пандемічне теперішнє ніяким чином не вплине на їхнє майбутнє. Вони не готові усвідомити невідворотність і неминучість змін, що, з одного боку, свідчить про гостроту травматичних переживань, з іншого - про брак життєвого досвіду. Трохи більше половини людей бачать впливи, які охоплюють і сьогодення, і більш-менш віддалене майбутнє. Щоправда, оптимістів серед них виразно більше, ніж песимістів, особливо серед жінок і молоді.

По-mpemє, до структури пандемічної повсякденності входять ціннісно-смислові характеристики життя, що проявляються у відповідних життєвих ландшафтах.

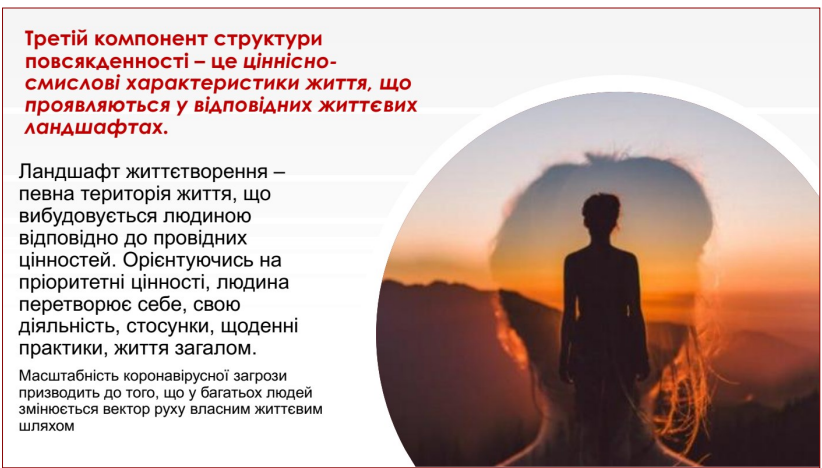

Ландшафт життєтворення є певною територією життя, що вибудовується людиною відповідно до цінностей, які $є$ важливими для неї на теперішній час і найближче майбутнє. Орієнтуючись на пріоритетні цінності, людина перетворює себе, свою діяльність, стосунки, щоденні практики, життя загалом. Ціннісно-смислова конфігурація і векторна спрямованість життя, яке вибудовує людина у складних життєвих ситуаціях, багато в чому залежить від характеру травмування і тривалості перебування у травматичній ситуації. Масштабність коронавірусної загрози призводить до того, що у багатьох людей змінюється вектор руху власним життєвим шляхом.

Коли людина потрапляє на іншу життєву територію, долає інакший ландшафт, трансформуються способи збереження і підвищення психологічного благополуччя. Перебування у карантинній ситуації внаслідок пандемії не всі сприймають як кризову ситуацію, що знижує благополуччя, оскільки рівень усвідомлення небезпеки дуже різний. 
За нашими даними, найбільш розповсюдженим виявився прагматичний ландшафт життетворення. Щоправда, лише для чоловіків. Вікова група, в якій цей ландшафт превалює, - молодь (26-37 рр.). У межах прагматичного ландшафту люди сприймають небезпеку перш за все раціонально, по-діловому. Вони зосереджуються на нових практиках, які треба освоювати у професійній діяльності, на змінах у повсякденному житті, спілкуванні, відпочинку тощо. Підкреслюється насамперед наявність робочих завдань, яких стало більше. Формуються чіткі плани на майбутнє, коригуються попередні плани. Основною цінністю стає користь нового досвіду.

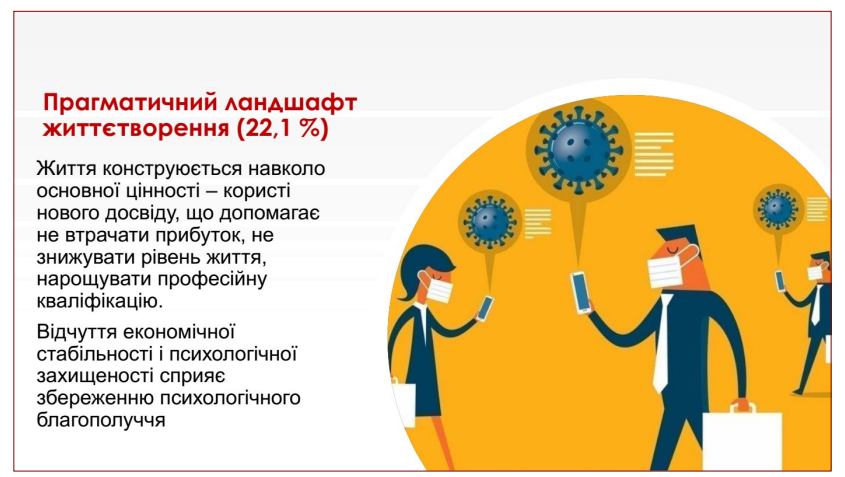

Саме прагматичний спосіб побудови власного життя для багатьох виявився найбільш прийнятним, адже найпростіше зберігати психологічне благополуччя, коли вдається концентруватися передовсім на роботі чи навчанні, намагаючись залишити власні професійні інтереси відносно константними. Якщо ситуація вимагає, людина швидко переорієнтовується на інакший спосіб заробляння грошей. Це дає змогу відволікатися від тривожних повідомлень, не втрачати прибуток, зберігати і підвищувати професійну кваліфікацію, звичний рівень життя сім'ї.

На другому місці за розповсюдженістю у нашій вибірці виявився екзистенційний ландшафт житmєтворення. На відміну від прагматичного екзистенційний ландшафт найчастіше обирали жінки. Він є найбільш розповсюдженим серед наймолодшої (19-25 рр.) і найстаршої (61-87рр.) вікових груп, хоча причини його популярності у юнацькому середовищі і середовищі людей, яких можна віднести до віку пізньої зрілості, безумовно, різні.

у межах екзистенційного ландшафту панує насамперед життєвий контекст, пов'язаний 3 пандемією. Ситуація, що склалася, оцінюється як прикра, небезпечна, складна і важка. Перебуваючи на території цього ландшафту, людина боляче

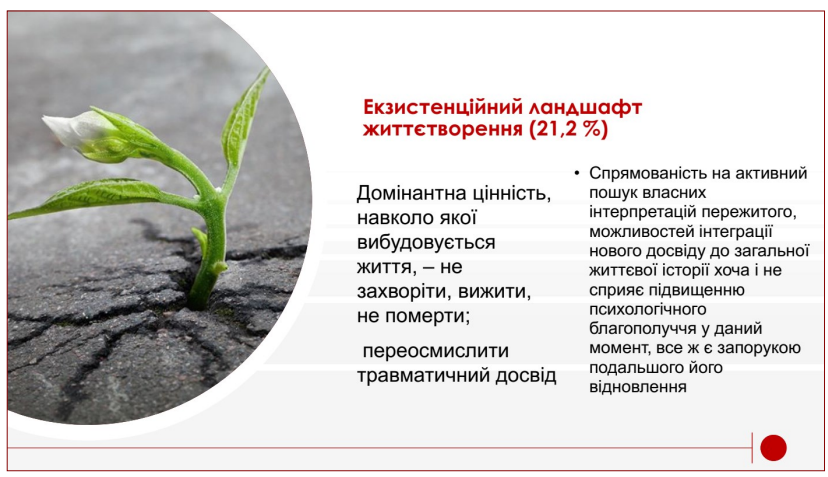

переживає всі негаразди, які принесла карантинна ситуація, дуже тривожиться за себе і своє найближче оточення, що накладає свій відбиток на минуле, теперішнє, майбутнє, на значущі стосунки, навчання, професійну діяльність. Домінантна цінність, навколо якої вибудовується життя, - не захворіти, вижити, не померти. Цим людям потрібен час і психологічна підтримка для того, щоб подолати стани тривоги, страху, небезпеки, які заважають об'єктивному баченню наявних в їхньому житті потенційних ресурсів для подолання.

Екзистенційний ландшафт на перший погляд $\epsilon$ найскладнішим для збереження психологічного благополуччя. Однак основне заняття тих, хто його долає, полягає у роботі переживання, в осмисленні актуального травматичного досвіду. За умови конструктивної внутрішньої роботи 3 травмою закладаються підвалини досить високого рівня психологічного благополуччя у майбутньому. Спрямованість на активний пошук власних інтерпретацій пережитого, можливостей інтеграції нового досвіду до загальної життєвої історії хоча і не сприяє підвищенню психологічного благополуччя у даний момент, все жє запорукою подальшого його відновлення. Йдеться про майбутнє підвищення психологічного благополуччя, можливо, навіть до більш високого рівня, ніж у представників прагматичного ландшафту. Адже останні не займаються спеціально осмисленням власної травматизації, що може згодом мати негативні наслідки.

На третьому місці за розповсюдженістю ландшафт саморозвитку, однаково популярний серед представників юнацтва, молоді і людей зрілого віку. Для гендерно відмінних частин вибірки цей ландшафт знаходиться на другому місці. І чоловіки, і жінки обирали цей ландшафт однаково часто, але чоловіки - після прагматичного, а жінки - після екзистенційного.

Люди, життєтворення яких відбувається в межах цього ландшафту, розцінюють карантинну 


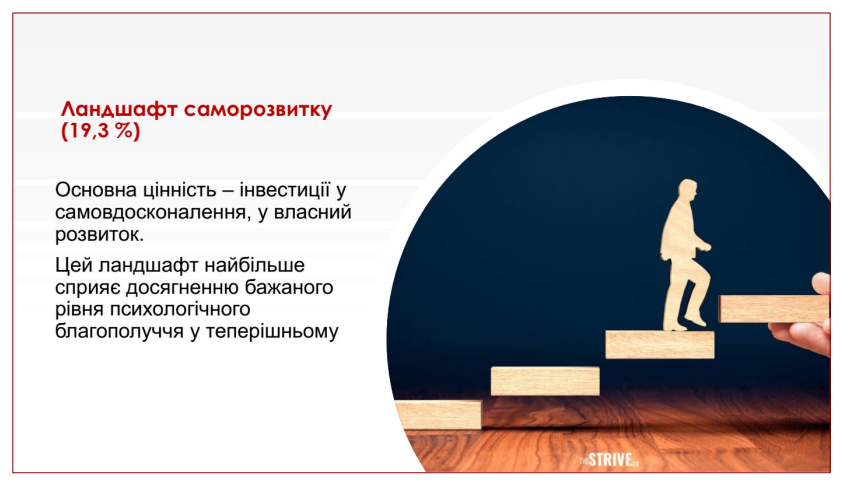

ситуацію не стільки як негативну, скільки як позитивну, бо сприймають її як ресурсну. Період життя всередині пандемічної повсякденності стає для них часом випробувань, потрібним для набуття нових навичок, появи більш конструктивних практик, для самовдосконалення у різних сферах. Майбутнє планується у межах основної цінності - інвестицій у власний розвиток.

Саме ландшафт саморозвитку найбільше сприяє досягненню бажаного рівня психологічного благополуччя у теперішньому. Знаходячись у межах цього ландшафту, люди не драматизують можливі вірусні ризики чи обмеження карантинної ситуації, а сприймають нові життєві обставини як виклик, як період, корисний для особистісного зростання, вдосконалення себе як людини, спеціаліста, батька чи матері. Всі плани, які вибудовуються на власне майбутнє, спрямовані на послідовний саморозвиток. Благополуччя підвищується і завдяки тому, що опору представники ландшафту саморозвитку шукають у самозаохоченні до творчої діяльності, у креативних формах проведення вільного часу.

Наступний за розповсюдженістю - комунікативний ландшафт життєтворення, серед представників якого жінок трохи більше, ніж чоловіків. Цей ландшафт є характерним для всіх вікових груп, крім пізньої зрілості, як і ландшафт саморозвитку. Особливо яскраво він представлений серед зрілих людей, займаючи у цій віковій групі перше місце за розповсюдженістю.

Головним для тих, хто вибудовує комунікативний ландшафт, є життєвий контекст спілкування 3 близькими, рідними, друзями. Під час локдауну комунікатори найбільше страждають від браку повноцінних, живих контактів, особливо з коханими, якщо ті під час карантину опинилися десь далеко. Не вистачає і контактів з колегами, друзями, знайомими. Пріоритетною цінністю виступають значущі, емоційно наповнені стосунки, сім'я, діти.

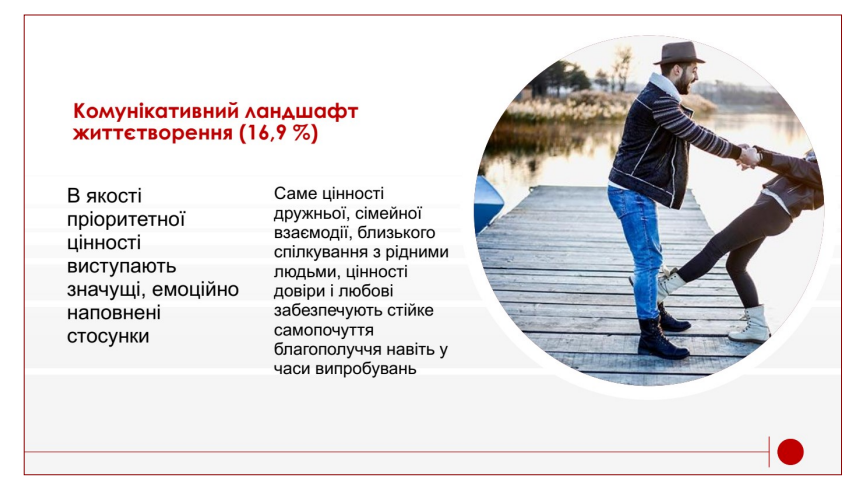

Вочевидь, головним способом збереження і підвищення психологічного благополуччя для тих, хто знаходиться у межах комунікативного ландшафту, $€$ якісне спілкування із значущим оточенням, що передбачає взаєморозуміння та взаємопідтримку. Саме цінності дружньої сімейної взаємодії, близького спілкування з рідними людьми, довіри і любові забезпечують стійке самопочуття благополуччя навіть у часи випробувань. Універсальний спосіб підтримки належного рівня психологічного благополуччя у складних життєвих умовах спрямований на пошук опори у почутті близькості, що виникає в процесі спілкування. Його мета - насамперед подолання почуття самотності, яке породжує неспокій, тривогу, посилює внутрішнє напруження.

Серед мало розповсюджених слід назвати соцієтальний і волонтерський ландшафти життєтворення.

Ті, хто долає соцієтальний ландшафрт, не концентрується лише на змінах у власному житті. Зазвичай крім особистого береться до уваги чимало соціальних контекстів пандемічного сьогодення (економічних, екологічних, політичних). Майбутнє теж планується не як суто індивідуальне, а як час для реалізації основної цінності збереження людства, очищення планети. Відповідно індивідуальне психологічне благополуччя для представників соцієтального ландшафту $\epsilon$ благополуччям людства. I тут складності полягають у тому, що людині важко знайти адекватні

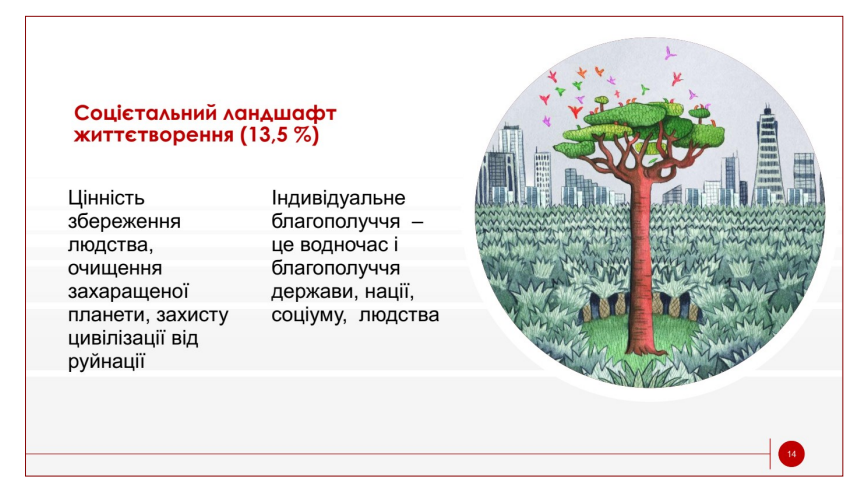


способи власної співучасті у збереженні прийнятного рівня економіки, прийнятті оперативних політичних рішень чи підвищенні загальної екологічної культури.

Представники волонтерського ландшафрту життєтворення не драматизують карантинну ситуацію, оцінюють її зважено. Зміни в їхньому житті пов'язані з переорієнтацією власної повсякденної активності на допомогу стареньким пенсіонерам, лікарям, медичним працівникам. Основна цінність для волонтерів - якомога більше зробити для людей, щоб допомогти подолати складні пандемічні часи. Їхнє психологічне благополуччя не падає, якщо $€$ можливість активно залучатися до профілактики коронавірусної хвороби. І чим інтенсивнішою стає така допомога, чим більше часу і сил людина витрачає на волонтерство, тим більше підвищується її психологічне благополуччя.

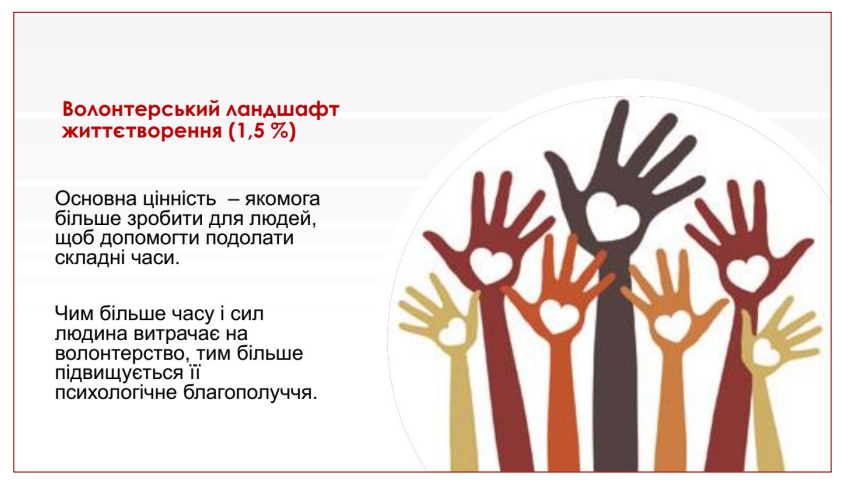

Таким чином, можливості збереження психологічного благополуччя В ситуації пандемії пов'язані:

- з життєвою ситуацією, яку людина певним чином сприймає, оцінює, переживає;

- зі змінами у житті, які проявляються в особливостях зв'язку переосмисленого минулого, оновленого теперішнього і більш-менш прогнозованого майбутнього;

- із ціннісно-смисловими характеристиками, що проявляються у відповідних ландшафтах життєтворення.

Зважене ставлення людини до пандемічної життєвої ситуації, в якій вона опинилася, позитивно впливає на психологічне благополуччя. Водночас негативні або позитивні поляризації оцінок утруднюють, гальмують прийняття обставин, які не можна змінити.

Зміни у житті людей, які відбуваються внаслідок пандемії і карантинних обмежень, проявляються в особливостях осмислення актуального досвіду. Якщо нові зв'язки між минулим, теперіш- нім і майбутнім не встановлюються, це знижує загальний рівень психологічного благополуччя. Структурування людиною власного майбутнього, що передбачає усвідомлення причиннонаслідкових зв'язків з теперішнім, сприяє підвищенню психологічного благополуччя. Оптимістичні прогнози можуть свідчити як про достатній рівень психологічного благополуччя, так і про силу психологічних захистів, що заважають усвідомленню і прийняттю суперечливого коронавірусного сьогодення.

Особливий вплив на збереження психологічного благополуччя мають ціннісно-смислові характеристики життя, що проявляються у відповідних життєвих ландшафтах. Найбільш позитивно впливає на актуальний стан психологічного благополуччя ландшафт саморозвитку, варіантами якого можна розглядати поки що мало представлені соцієтальний і волонтерський ландшафти. Мають свою специфіку і способи збереження психологічного благополуччя, які використовують представники прагматичного та комунікативного ландшафтів. У більш віддаленій часовій перспективі психологічне благополуччя може залежати і від якості переосмислення травматичного досвіду, що забезпечує екзистенційний ландшафт життєтворення.

Для багатьох людей, яким не вистачає внутрішніх ресурсів для збереження психологічного благополуччя у травматичний і посттравматичний період, потрібна соціальна і психологічна підтримка. Вона надається близькими людьми, спільнотами та професіоналами: психологами, психотерапевтами, соціальними працівниками. Ефективною формою підтримки стає соціальнопсихологічний супровід як медіатор особистісного життєтворення, що передбачає відновлення психологічного здоров'я, життєстійкості, покращення стосунків з оточенням, повнішу професійну самореалізацію.

\section{СПИСОК ВИКОРИСТАНИХ ДЖЕРЕЛ}

Гаврищак, Л., \& Борисенко, 3. (2019). Щастя як психологічна категорія. Проблеми гуманітарних наук. Серія: Психологія, (45), 39-51. http://nbuv.gov.ua/ UJRN/Pgn_ps_2019_45_5

Гілберт, Д. (2019). Спотикаючись об щастя. Позитивна психологія. Харків: Книжковий клуб «Клуб Сімейного Дозвілля».

Максименко, С., \& Лущ-Пурій, У. (упор.). (2020). Щастя та сучасне суспільство : збірник матеріалів міжнародної наукової конференції (Львів, 20-21 березня 2020 р.). Львів: СПОЛОМ. https:// doi.org/10.31108/7.2020 
Слюсаревський, М.М. (ред.). (2020). Життєвий світ і психологічна безпека людини в умовах суспільних змін. Київ: Талком, 2020. https://lib.iitta.gov.ua/722833/

Титаренко, Т.М. (2020а). Особистісне повсякдення в умовах пандемії: константи і трансформації. In Горизонти посттравматичного особистісного життєтворення : матеріали Всеукраїнського науково-практичного семінару (с. 7-11). Київ: ІСПП НАПН України. https://cutt.ly/7vRuSNF
Титаренко, Т.М. (2020b). Посттравматичне життєтворення: способи досягнення психологічного благополуччя : монографія. Кропивницький : ІмексЛТД. https://bit.ly/3mln3zq

Brooks, S., Dunn, R., Amlôt, R., Rubin, G., \& Greenberg, N. (2017). Social and occupational factors associated with psychological wellbeing among occupational groups affected by disaster: a systematic review. Journal of Mental Health, 26(4), 373-384. https:// doi.org/10.1080/09638237.2017.1294732

\title{
POSSIBILITIES OF PSYCHOLOGICAL WELL-BEING PRESERVING IN A PANDEMIC SITUATION
}

\author{
Scientific report at the methodological seminar of the National Academy of Educational Sciences of Ukraine \\ "Actual Problems of Psychological Resistance to Harmful Information Impact on Personality \\ under Current Challenges" (April 8, 2021) \\ Tetiana Tytarenko \\ DSc in Psychology, Professor, Full Member (Academician) of NAES of Ukraine, Chief Research Fellow of \\ the Laboratory for Social Psychology of Personality, Institute for Social and Political Psychology of \\ the National Academy of Educational Science of Ukraine, Kyiv, Ukraine
}

Abstract. It is determined that the possibilities of maintaining psychological well-being in a pandemic situation are related (1) to the life situation that a person perceives, evaluates, experiences in a certain way; (2) with changes in life, which are manifested in the peculiarities of the connection between the rethought past, the renewed present and the more or less predicted future; (3) with value and semantic characteristics that are manifested in the relevant lifelandscapes. It was found that the landscape of self-development has the most positive effect on the current state of psychological well-being. Different ways to preserve psychological well-being are used by representatives of pragmatic, communicative, societal, volunteer landscapes. In the longer term, psychological well-being may depend on the quality of rethinking the traumatic experience that provides the existential life-landscape.

Social and psychological support with the participation of psychologists, psychotherapists, social workers, community representatives is provided to those people who lack the internal resources to maintain psychological wellbeing. An effective form of help is socio-psychological support as a mediator of personal life, which involves the restoration of psychological health, resilience, improving relationships with others, fuller professional self-realization.

Keywords: psychological well-being; assessment of the quarantine situation; changes in the past-present-future; value and semantic characteristics of life; landscape of life; COVID-19 pandemic.

Дата публікації: 19 квітня 2021 р. 